\title{
Pp65 antigenemia, plasma real-time PCR and DBS test in symptomatic and asymptomatic cytomegalovirus congenitally infected newborns
}

\author{
Sandro Binda ${ }^{*}$, Antonella Mammoliti ${ }^{1}$, Valeria Primache ${ }^{1}$, Patrizia Didò ${ }^{1}$, Carlo Corbetta ${ }^{2}$, Fabio Mosca ${ }^{3}$, \\ Lorenza Pugni ${ }^{3}$, Anna Bossi ${ }^{4}$, Cristian Ricci ${ }^{4}$, Maria Barbi ${ }^{1}$
}

\begin{abstract}
Background: Many congenitally cytomegalovirus-infected (cCMV) neonates are at risk for severe consequences, even if they are asymptomatic at birth. The assessment of the viral load in neonatal blood could help in identifying the babies at risk of sequelae.

Methods: In the present study, we elaborated the results obtained on blood samples collected in the first two weeks of life from 22 symptomatic and 48 asymptomatic newborns with CCMV diagnosed through urine testing. We evaluated the performances of two quantitative methods (pp65 antigenemia test and plasma Real-time PCR) and the semi-quantitative results of dried blood sample (DBS) test in the aim of identifying a valid method for measuring viral load.
\end{abstract}

Results: Plasma qPCR and DBS tests were positive in $100 \%$ of cases, antigenemia in $81 \%$. Only the latter test gave quantitatively different results in symptomatic versus asymptomatic children. qPCR values of $10^{3} \mathrm{copies} / \mathrm{ml}$ were found in 52\% of newborn. "Strong" DBS test positivity cases had higher median values of both pp65 positive PBL and DNA copies/ml than cases with a "weak" positivity.

Conclusions: As expected antigenemia test was less sensitive than molecular tests and DBS test performed better on samples with higher rates of pp65 positive PBL and higher numbers of DNA copies $/ \mathrm{ml}$. The prognostic significance of the results of these tests will be evaluated on completion of the ongoing collection of follow-up data of these children.

\section{Background}

Congenital cytomegalovirus infection (cCMV) is present in $0.7 \%$ of neonates [1] and represents one of the most feared events during pregnancy, causing not only immediate but also delayed sequelae to the infant. At birth, $10 \%$ of infected newborns present with symptoms involving the hematopoietic, hepatobiliary, or central nervous systems.

During early childhood, one fifth of all congenitally infected babies either die or suffer permanent neurological impairments that can affect normal development, particularly psychomotor retardation, ocular damage, or sensorineural hearing loss (SNHL). This last sequelae is

\footnotetext{
*Correspondence: sandro.binda@unimi.it
'Dipartimento di Sanità Pubblica - Microbiologia - Virologia, Università degli

* Correspondence: sandro.binda@unimi.it
'Dipartimento di Sanità Pubblica - Microbiologia - Virologia, Università degli Studi di Milano, Milan, Italy
}

( 2010 Binda et al; licensee BioMed Central Ltd. This is an Open Access article distributed under the terms of the Creative Commons Attribution License (http://creativecommons.org/licenses/by/2.0), which permits unrestricted use, distribution, and reproduction in any medium, provided the original work is properly cited. may be evident at birth (45-65\%) [1] or develop later. Moreover, there may be different degrees of severity and it may be progressive.

As corrective measures may only be successful if carried out immediately, having diagnostic tools available to promptly identify an infected child is essential. This is most useful for children with late-onset SNHL, since the median age for detection of hearing loss is of 27 months (range, 25-62 months) [2].

It is also important to use virological markers that indicate an unfavorable prognosis to identify newborns at risk of developing serious problems. This forms the basis for organizing close follow-up, early rehabilitation, and/or therapy to minimize long-term damage. 
The viral load in biological samples, such as urine and peripheral blood leukocytes (PBL) during the neonatal period was proposed by some investigators as a prognostic marker of developing hearing loss [3-6].

In this study we evaluated the quantitative results of two blood assays (pp65 antigenemia test and Real-time PCR) and the semi-quantitative results of dried blood sample (DBS) test, obtained in our routine diagnostic activity, in the aim of identifying a valid method for measuring viral load. On completion of the ongoing collection of follow-up data of the studied children, it will be possible to assess its prognostic significance.

\section{Methods}

\section{Cases}

In this study we retrieved and elaborated the results of tests previously performed in our laboratory on blood samples as part of the protocol for cCMV diagnosis. Samples had been collected from 70 consecutive newborns (32 females and 38 males) whose cCMV infection had been diagnosed on the basis of a positive rapid isolation test (SV assay) from urine specimens collected in the first two weeks of life.

Twenty-two newborns (31\%) showed symptoms of congenital infection at birth [7]. The other 48 newborns were asymptomatic: 44 of these had been examined having been delivered from mothers with a confirmed primary infection during pregnancy and 2 were identified during a study of newborns from HIV+ mothers, while evidence of exposure to risk factors was not indicated for the 2 remaining newborns.

No data of follow-up are available yet.

Since this was a retrospective and methodological study on the results already available with us, it was not put up for any clearance to an ethical committee. All the patient files are confidential and none could be identified.

\section{Methods}

\section{Antigenemia test (pp65)}

The leukocyte fraction (PBL) was separated from each blood sample for antigenemia testing in IF assay (CINA pool pp65, Argene). The result was expressed as the number of positive cells in $2 \times 10^{5}$ PBL [8].

\section{Real-time Quantitative PCR ( $q P C R$ )}

CMV-DNA was extracted from $200 \mu \mathrm{l}$ of separated plasma using the QIAamp DNA Mini kit (QIAGEN) according to the manufacturer's protocol. The amount of viral DNA extracted was then measured in a commercial quantitative PCR assay (Q-CMV Real Time Complete Kit, Nanogen) following the supplier's instructions. The results were expressed as copies $/ \mathrm{ml}$.

\section{DBS test}

Viral DNA in dried blood samples (DBS test) from newborns was tested as described by Binda et al. [9]. CMV DNA was eluted from 3-mm diameter disks, extracted by means of thermal shock and used as the template for a nested PCR specific for a highly conserved region of the CMV gB gene (nt 1942 - nt 2067) [10]. The result was interpreted following an algorithm described by Barbi et al. [11], requiring that the test be done on three series of punches.

The positive results were distinguished as:

- "strong" if at least two out of three tests were positive

- "weak" if one out of three tests was confirmed positive in a further series of three.

\section{Statistical analysis}

The association between DBS test results (weak or strong) and the presence of symptoms was tested using Fisher's exact test, while the Mann-Whitney $U$ test was performed to compare symptomatic and asymptomatic newborn's median number of positive cells in the pp65 antigenemia test, and the median number of CMV DNA copies detected by qPCR. A p-value of 0.05 was considered significant.

\section{Results and discussion}

Results from the blood samples of all 70 neonates were obtained with the DBS test, whilst the presence of inhibitors hampered the assessment of the number of DNA copies by qPCR in the plasma of three children, and the low PBL counts precluded the determination of the pp65 antigenemia in two cases.

The pp65 antigenemia test was positive in $81 \%(55 / 68)$ of samples tested. Compared with children who had asymptomatic infections, those with symptoms had a

Table 1 Results of the pp65 (antigenemia), qPCR, and DBS tests in symptomatic and asymptomatic newborns

\begin{tabular}{|c|c|c|c|c|c|c|c|c|c|}
\hline & \multicolumn{3}{|c|}{ pp65 (no. cells pos $/ 2 \times 10^{5} \mathrm{PBL}$ ) } & \multicolumn{3}{|c|}{ qPCR (no. copies $/ \mathrm{ml}$ ) } & \multicolumn{3}{|c|}{ DBS test } \\
\hline & Positive (\%) & Median & IQR $^{\circ}$ & Positive (\%) & Median & $\mathrm{IQR}^{\circ}$ & Positive (\%) & Weak & Strong \\
\hline Symptomatic & $19 / 21(90.5 \%)$ & 8.0 & $2-33$ & $22 / 22(100.0 \%)$ & 8,701 & $1,777-39,945$ & $22 / 22(100.0 \%)$ & 3 & 19 \\
\hline Asymptomatic & $36 / 47$ (76.6\%) & 3.0 & $2-7$ & $45 / 45(100.0 \%)$ & 5,383 & 2,359-11,896 & 48/48 (100.0\%) & 7 & 41 \\
\hline$p$ & \multicolumn{3}{|c|}{$0.0098^{*}$} & \multicolumn{3}{|c|}{$0.2193^{*}$} & \multicolumn{3}{|c|}{$0.2858^{* *}$} \\
\hline
\end{tabular}

${ }^{\circ} \mathrm{IQR}=$ interquartile range

* Mann -Whitney test

** Fisher's exact test 


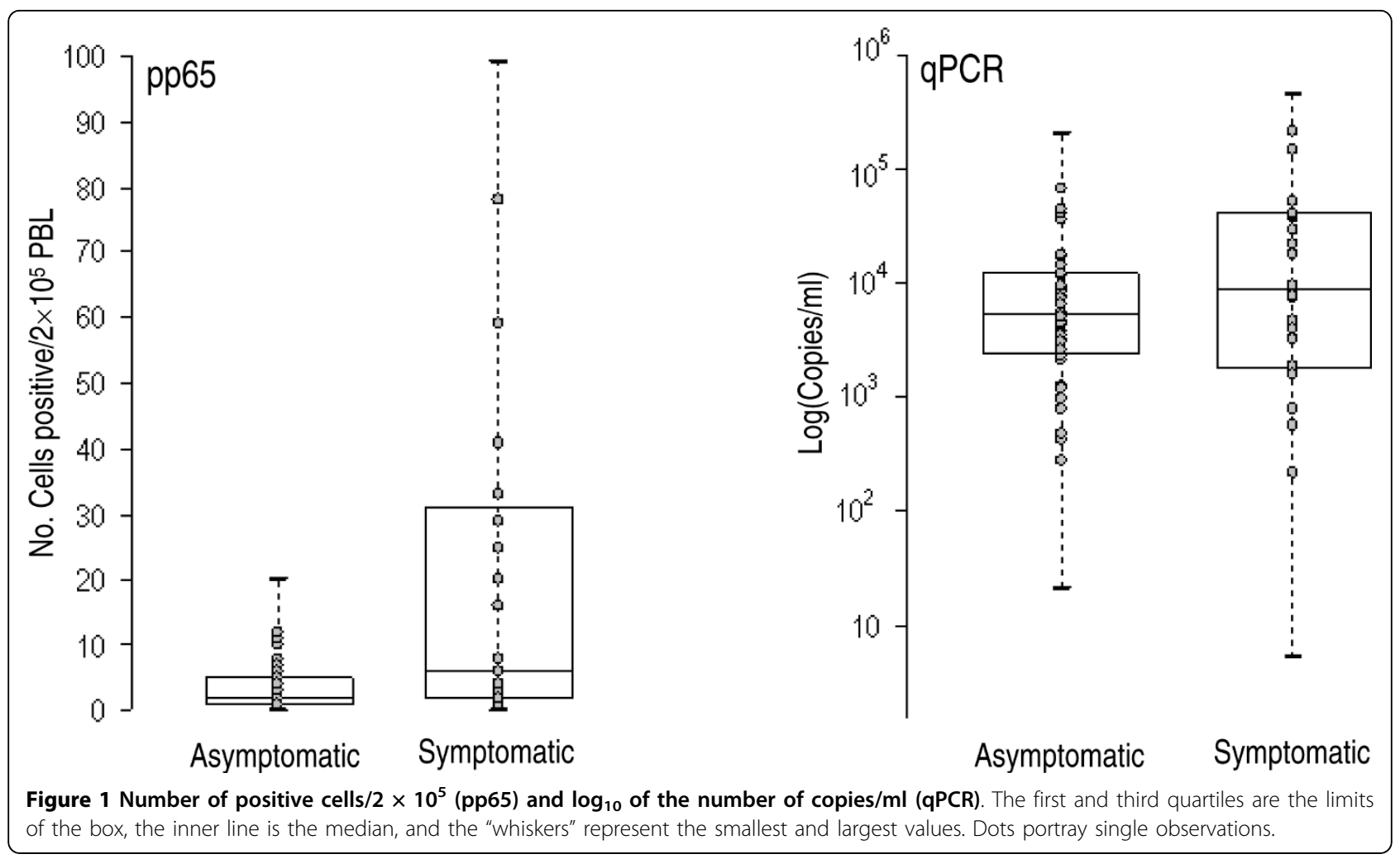

non-significant, higher degree of positive results $(90 \%$ vs. $77 \% ; \mathrm{p}=0.3110)$, and the median value of positive cells was significantly higher $(\mathrm{p}=0.0098)$ (Table 1$)$. Children with neurological symptoms had median values (31 positive cells $/ 2 \times 10^{5} \mathrm{PBL}$ ) higher than symptomatic babies with only abnormal biological parameters ( 2 positive cells $/ 2 \times 10^{5}$ PBL; $\mathrm{p}=0.0218$ ).

All 67 plasma samples suitable for qPCR were positive. The order of magnitude of the viral load was $10^{3}$ copies $/ \mathrm{ml}$ in $52 \%$ of cases (35/67), of whom $80 \%$ were asymptomatic. However, there were no significant differences between the median number of DNA copies $/ \mathrm{ml}$ in relation to the presence or absence of symptoms $(\mathrm{p}=$ 0.22 , Table 1 ) or to the involvement of CNS in symptomatic babies $(37,000$ vs 7,300 copies $/ \mathrm{ml} ; \mathrm{p}=0.0878)$. As shown in Figure 1, greater variability was detected with the antigenemia test among symptomatic children than in asymptomatic ones, but not with qPCR.

Sixty neonates were strong positives in DBS test whereas the remaining 10 (14\%) were weak positives. The DBS test results as with qPCR were not related to the presence or absence of symptoms at birth $(\mathrm{p}>0.05$; Table 1) nor to the involvement of CNS ( $p>0.05$ ). The median number of positive cells in the antigenemia test and copies $/ \mathrm{ml}$ were significantly higher in children with strong positivity in the DBS test than in those with weakly positive findings (Table 2).

\section{Conclusions}

In this study, two quantitative methods (the pp65 antigenemia test and $\mathrm{qPCR}$ ) were compared with semiquantitative DBS test to assess the clinical relevance of hCMV load determination in infected babies both symptomatic and asymptomatic at birth.

In this and a previous study [8], the sensitivity of the antigenemia test to identify an infection was $81 \%\left(\mathrm{CI}_{95 \%}\right.$ : 69.3 to 89.1 ) and $84 \%$, respectively, which was higher than the $42 \%$ reported by Revello et al. [3]. This difference might be because of the smaller proportion of

Table 2 pp65 antigenemia and qPCR findings in children with either a weakly or strongly positive DBS-test

\begin{tabular}{|c|c|c|c|c|}
\hline & \multicolumn{4}{|c|}{ Positive DBS test } \\
\hline & \multicolumn{2}{|c|}{$\begin{array}{c}\text { pp65 } \\
\text { (no. cells pos } / 2 \times \\
10^{5} \mathrm{PBL} \text { ) }\end{array}$} & \multicolumn{2}{|c|}{$\begin{array}{c}\text { qPCR } \\
\text { (copies/ml) }\end{array}$} \\
\hline & weak & strong & weak & strong \\
\hline Total & 10 & 58 & 8 & 59 \\
\hline Positive (\%) & $\begin{array}{c}7 \\
(70.0 \%)\end{array}$ & $\begin{array}{c}48 \\
(82.8 \%)\end{array}$ & $8(100 \%)$ & 59 (100\%) \\
\hline Median & 1.0 & 4.5 & 1,318 & 7,753 \\
\hline $\begin{array}{l}\text { Interquartile range } \\
\text { (IQR) }\end{array}$ & $1-4$ & $2-11.8$ & $\begin{array}{l}501- \\
3,327\end{array}$ & $\begin{array}{l}3,136- \\
17,916\end{array}$ \\
\hline$p$ & \multicolumn{2}{|c|}{$0.0385^{*}$} & \multicolumn{2}{|c|}{$0.0279^{*}$} \\
\hline
\end{tabular}

* Mann -Whitney test 
symptomatic neonates in the latter study. However all these studies showed significantly higher median counts of pp65 positive PBLs in symptomatic cases. The significant difference in terms of pp65 positive PMN cells, but not as plasma CMV DNA copies/ml, in relation to the clinical situation at birth might be related to the type of sample. Revello [3] and Lanari [5] detected significant differences of viral load. testing fixed amounts of PBLs

Viral DNA was detected by PCR in the acellular blood fraction of all the infants, as observed in other studies $[12,13]$, confirming the higher sensitivity of molecular tests compared with immunological ones.

The quantitative PCR detected a median number of copies/ml of the same order of magnitude $\left(10^{3}\right)$ as that reported by Halwachs-Baumann et al. [14] even if they tested serum and not plasma. Bradford et al. detected levels that were about one logarithm lower in children with symptomatic infections involving the central nervous system [15]. These viral load values could affect the DBS test findings; in an external quality assessment study, about half the laboratories were unable to detect DNA from blood with a viral load of $10^{3}$ copies/ml [16]. Of note, we noticed that there was a loss of titer of about one log between fresh and dried blood samples.

As described in a review by Barbi et al. [11], the DBS test must be repeated on a new series of three samples to confirm a single positivity in about $10 \%$ of cases, suggesting that this is indicative of a low viral load in the blood. This was confirmed by the present study, where a lower median level of both pp65-positive cells and DNA copies was detected in weakly positive DBS samples, corresponding to $14 \%$ of all those tested. Therefore, some of these cases were probably at the limit of sensitivity and may be missed with DBS testing, particularly if the method employed (sample size, elution, extraction, amplification) and the algorithm for defining positivity are less than optimal. Hence, it is necessary to correctly perform this test and properly interpret the test results.

A comparison of the semi-quantitative measures obtained in DBS test with the quantitative results of real-time PCR on the same samples is ongoing.

Finally, upon completion of clinical and audiological follow-up, the prognostic value of quantitative and semi-quantitative results could be assessed.

\footnotetext{
Acknowledgements

This study was supported in part by funding from Ministero della Salute within the "Programma di ricerca sanitaria finalizzata - anno 2006" in the framework of the project "Prevenzione, diagnosi, prognosi e terapia delle infezioni virali nella gestante, nel feto e nel neonato".
}

\section{Author details}

'Dipartimento di Sanità Pubblica - Microbiologia - Virologia, Università degli Studi di Milano, Milan, Italy. ${ }^{2}$ Laboratorio di Riferimento Regionale per lo
Screening Neonatale, AO ICP, Milan, Italy. ${ }^{3}$ Istituto di Pediatria e Neonatologia, Fondazione IRCCS "Ospedale Maggiore Policlinico, Mangiagalli e Regina Elena", Università degli Studi di Milano, Milan, Italy. ${ }^{4}$ Istituto di Statistica Medica e Biometria "GA Maccacaro", Università degli Studi di Milano, Milan, Italy.

\section{Authors' contributions}

$S B, A M, V P, P D, M B$ participated in the conception and design of study, performed the assays and contributed to the preparation of the manuscript. CC, FM, LP provided clinical data and contributed to draft the manuscript. $A B$ and $C R$ performed the statistical analysis of the results and provided critical comments to improve the manuscript. All authors read and approved the final manuscript.

\section{Competing interests}

The authors declare that they have no competing interests.

Received: 16 June 2009

Accepted: 11 February 2010 Published: 11 February 2010

\section{References}

1. Dollard SC, Grosse SD, Ross DS: New estimates of the prevalence of neurological and sensory sequelae associated with congenital cytomegalovirus infection. Red Med Virol 2007, 17(5):355-363.

2. Fowler KB, MC Collister FP, Dahle AJ, Boppana SB, Britt WJ, Pass RF: Progressive and fluctuating sensorineural hearing loss in children with asymptomatic congenital Cytomegalovirus infection. J Pediatr 1997, 130:624-630

3. Revello MG, Zavattoni M, Baldanti F, Sarasini A, Paolucci S, Gerna G: Diagnostic and prognostic value of human cytomegalovirus load and IgM antibody in blood of congenitally infected newborns. J Clin Virol 1999, 14:57-66.

4. Boppana SB, Fowler KB, Pass RF, Rivera LB, Bradford RD, Lakeman FD, Britt WJ: Congenital cytomegalovirus infection: association between virus burden in infancy and hearing loss. J Pediatr 2005, 146:817-823.

5. Lanari M, Lazzarotto T, Venturi V, Papa I, Gabrielli L, Guerra B, Landini MP, Faldella G: Neonatal cytomegalovirus blood load and risk of sequelae in symptomatic and asymptomatic congenitally infected newborns. Pediatrics 2006, 117:76-83.

6. Walter S, Atkinson C, Sharland M, Rice P, Raglan E, Emery VC, Griffiths PD: Congenital cytomegalovirus: association between dried blood spot viral load and hearing loss. Arch Dis Child Fetal Neonatal 2008, 93:F280-F285.

7. Dobbins JG, Stewart JA, Demmler JG: Surveillance of congenital cytomegalovirus disease, 1990-1991. CDC surveillance summaries: MMWR 1992, 41(SS-2):35-44.

8. Barbi M, Binda S, Primache V, Novelli C: Cytomegalovirus in peripheral blood leukocytes of infants with congenital or postnatal infection. Pediatr Infect Dis J 1996, 15:898-903.

9. Binda S, Caroppo S, Didò P, Primache V, Veronesi L, Calvario A, Piana A, Barbi M: Modification of CMV DNA detection from dried blood spots for diagnosing congenital CMV infection. J Clin Virol 2004, 30:276-279.

10. Wakefield AJ, Fox JD, Sawyerr AM, Taylor JE, Sweenie CH, Smith M, Emery VC, Hudson M, Tedder RS, Pounder RE: Detection of herpesvirus DNA in the large intestine of patients with ulcerative colitis and Crohn's disease using the nested polymerase chain reaction. J Med Virol 1992, 38:183-190,

11. Barbi M, Binda S, Caroppo S: Diagnosis of congenital CMV infection via dried blood spots. Rev Med Virol 2006, 16:385-392.

12. Brytting $M, X u$ W, Wahren B, Sundqvist V: Cytomegalovirus DNA detection in sera from patients with active cytomegalovirus infections. J Clin Microbiol 1992, 30:1937-1941.

13. Barbi M, Binda S, Minolfi V, Novelli C, Primache V, Tagger A: HCMV infection diagnosis by detection of viral DNA by PCR in serum or plasma. Presented at the European Group for Rapid Diagnosis (EGRVD) Meeting. Stockholm 1994.

14. Halwachs-Baumann G, Genser B, Pailer S, Engele H, Rosegger H, Schalk A, Kessler HH, Truschnig-Wilders M: Human cytomegalovirus load in various body fluids of congenitally infected newborns. J Clin Virol 2002, 25: S81-S87.

15. Bradford RD, Cloud G, Lakeman A, Boppana SB, Kimberlin DW, Jacobs R, Demmler G, Sanchez P, Britt W, Soong S, Whitley RJ, the National Institute 
of Allergy and Infectious Diseases Collaborative Antiviral Study Group:

Detection of cytomegalovirus (CMV) DNA by polymerase chain reaction

is associated with hearing loss in newborns with symptomatic

congenital CMV infection involving the central nervous system. J Infect

Dis 2005, 191:227-233.

16. Barbi M, Mackay WG, Binda S, van Loon A: External quality assessment of cytomegalovirus DNA detection on dried blood spots. BMC Microbiology $2008,8: 2$.

\section{Pre-publication history}

The pre-publication history for this paper can be accessed here:http://www. biomedcentral.com/1471-2334/10/24/prepub

doi:10.1186/1471-2334-10-24

Cite this article as: Binda et al:: Pp65 antigenemia, plasma real-time PCR and DBS test in symptomatic and asymptomatic cytomegalovirus congenitally infected newborns. BMC Infectious Diseases 2010 10:24.

\section{Submit your next manuscript to BioMed Central} and take full advantage of:

- Convenient online submission

- Thorough peer review

- No space constraints or color figure charges

- Immediate publication on acceptance

- Inclusion in PubMed, CAS, Scopus and Google Scholar

- Research which is freely available for redistribution

Submit your manuscript at www.biomedcentral.com/submit 